\title{
Gaya Kepemimpinan Kepala Madrasah Tsanawiyah Negeri 6 Kediri
}

\author{
Mohamad Ikhwanul Kirom, ${ }^{1}$ Suko Susilo ${ }^{2}$ \\ ${ }_{1}^{1}$ Pascasarjana Institut Agama Islam Tribakti Kediri, 2 Institut Agama Islam Tribakti Kediri \\ 1dmcosurabaya@gmail.com,2sukosusilo.ag1no@gmail.com
}

\begin{abstract}
The Head of Madrasa in the Education Unit is a leader. He has two positions: formal leader and school manager. In carrying out their duties, each madrasa head uses different strategies and methods according to his character, known as the leadership style. This research is a type of qualitative research with a descriptive-analytical approach. The sampling technique used is purposive sampling. So the source of data in this study is the headmaster of madrasas, educators, education staff, students, and documents related to the leadership style of the headmaster. The data collection techniques that researchers use in this thesis are observation, interviews and documentation. Data analysis techniques used are data collection, data reduction, data presentation and drawing conclusions. Indications for obtaining maximum results are observations about madrasah head decision making, madrasah head interaction models, madrasah head motivation, orientation/leadership behaviour of madrasas. The results show that, First, the leadership style of the head of MTs Negeri 6 Kediri is situational or combines democratic, authoritarian, laissez-faire but more dominant democracy. Secondly, this madrasa has indeed achieved many achievements at the district, provincial and national levels.
\end{abstract}

Keywords: Leadership Style, Head Master

\begin{abstract}
Abstrak
Kepala Madrasah dalam Satuan Pendidikan merupakan pemimpin. Dia mempunyai dua jabatan yaitu sebagai pemimpin formal dan pengelola sekolah. Dalam melaksanakan tugasnya setiap kepala madrasah menggunakan strategi dan cara yang berbeda-beda sesuai dengan karakternya, yang dikenal dengan sebutan gaya kepemimpinan. Penelitian ini merupakan jenis penelitian kualitatif dengan pendekatan deskriptif analitis. Teknik sampling yang digunakan adalah purpose sampling. Jadi sumber data dalam penelitian ini adalah kepala madrasah, pendidik, tenaga kependidikan, peserta didik, serta dokumen-dokumen terkait dengan gaya kepemimpinan kepala madrasah. Adapun teknik pengumpulan data yang peneliti gunakan dalam tesis ini adalah observasi, wawancara dan dokumentasi. Teknik analisis data yang digunakan adalah pengumpulan data, reduksi data, penyajian data dan penarikan kesimpulan. Indikasi untuk memperoleh hasil yang maksimal yaitu observasi tentang pengambilan keputusan kepala madrasah, model interaksi kepala madrasah, motivasi kepala madrasah, orientasi/ perilaku
\end{abstract}


kepemimpinan kepala madrasah. Hasil penelitian menunjukkan bahwa, Pertama, gaya kepemimimpinan kepala MTs Negeri 6 Kediri adalah situasional atau memadukan antara demokratis, otoliter, laissez-faire namun lebih dominan demokrasi. Kedua, madrasah ini memang sudah banyak meraih prestasi baik di tingkat kabupaten, provinsi maupun nasional.

\section{Kata Kunci: Gaya Kepemimpinan, Kepala sekolah}

\section{Pendahuluan}

Kepala sekolah sebagai pemimpin satuan pendidikan merupakan figur kunci dalam mendorong perkembangan dan kemajuan sekolah. Keberhasilan suatu lembaga pendidikan sangat tergantung pada kepemimpinan kepala sekolah. Karena kepala sekolah merupakan pemimpin di lembaganya, maka ia harus mampu membawa lembaganya ke arah tercapainya tujuan yang telah ditetapkan, ia harus mampu melihat adanya perubahan serta mampu melihat masa depan dalam kehidupan global yang lebih baik. Kepala sekolah sebagai seorang pendidik, administrator, pemimpin, dan supervisor diharapkan dengan sendirinya dapat mengelola lembaga pendidikan ke arah perkembangan yang lebih baik dan dapat menjajikan masa depan. ${ }^{1}$

Kepemimpinan merupakan topik menarik untuk dikaji. Oleh karena itu, sampai saat ini terus dipelajari dan diteliti. Kepemimpinan tidak bisa dilepaskan dari sebuah kekuasaan karena tanpa sebuah kekuasaan, pemimpin tidak memiliki kewenangan dalam mempengaruhi orang lain atau bawahan sebagaimana peran kepala sekolah dalam mengelola sebuah lembaga pendidikan yang ia pimpin. Oleh karena itu, Perilaku kepala sekolah harus dapat mendorong kinerja para guru dengan menunjukkan rasa bersahabat, dekat, dan penuh pertimbangan terhadap para guru, baik sebagai individu maupun sebagai kelompok. Sehingga para guru bisa meningkatkan kinerjanya dalam mejalankan tugas, dan merasa memiliki tanggung jawab yang harus mereka laksanakan. Agar kepala sekolah dapat melaksanakan tugasnya sebagai pemimpin secara efektif dan lancar, perlu memperhatikan faktor-faktor yang mendukung kepemimpinan. Faktorfaktor yang mendukung kepemimpinan adalah (1) komunikasi, (2) kepribadian, (3) keteladanan, (4) tindakan, dan (5) memfasilitasi. Kelima faktor inilah yang perlu diperhatikan dan dilaksanakan secara baik oleh kepala sekolah jika ingin sukses dalam memimpin. Begitu pun dalam lembaga pendidikan, kepala sekolah merupakan sosok pemimpin di dalam lembaga pendidikan. Segala kegiatan pendidikan baik kegiatan manajerial dan akademis, kepala sekolah

${ }^{1}$ Marno dan Triyo Supriyatno, Manajemen dan 
berperan mengawasi dan mengontrol kinerja para guru, memperhatikan tugastugas guru dan staf. Gaya kepemimpinannya menjadi suatu stimulus bagi para guru dan staf untuk menjalankan tugas dan kewajibannya dengan baik, apabila tercipta iklim organisasi yang baik di dalam sekolah. Kepala sekolah tidak hanya bertanggung jawab atas jalannya sekolah dengan kondisi dan situasinya serta hubungan dengan masyarakat sekitarnya merupakan tanggung jawabnya pula. Inisiatif dan kreatif yang mengarah kepada perkembangan dan kemajuan sekolah adalah merupakan tugas dan tanggung jawab kepala sekolah. ${ }^{2}$

Kepemimpinan

pendidikan berkaitan dengan masalah kepala sekolah dalam meningkatkan kesempatan untuk mengadakan peretemuan secara efektif dengan para guru dalam situasi yang kondusif. Maka dari itu, perilaku kepala sekolah harus mendorong kinerja para guru dengan menunjukkan rasa bersahabat, dekat, dan penuh pertimbangan terhadap para guru, baik sebagai individu maupun sebagai kelompok. Perilaku kepala sekolah yang positif dapat mendorong, mengarahkan, dan memotivasi seluruh warga sekolah untuk bekerja sama dalam mewujudkan visi, misi, dan tujuan sekolah. ${ }^{3}$

Proses kepemimpinan kepala sekolah berkaitan dengan gaya kepemimpinan yang digunakannya. Dari berbagai gaya kepemimpinan kepala sekolah gaya kepemimpinan situasional lebih fleksibel dalam kondisi operasional sekolah. Gaya kepemimpinan situasional berangkat dari anggapan bahwa tidak ada gaya kepemimpinan kepala sekolah yang terbaik, melainkan bergantung pada situasi dan kondisi sekolah. Situasi dan kondisi tersebut antara lain meliputi tingkat kematangan guru dan staf, yang dapat dilihat dari dua dimensi, yakni dimensi kemampuan dan dimensi kemauan. ${ }^{4}$

Ada berbagai macam gaya kepemimpinan yang diterapkan oleh kepala sekolah, ada pemimpin yang menerapkan gaya kepemimpinan yang otoriter dan hal ini cenderung akan direspon negatif oleh bawahannya dengan menunjukkan tingkat kinerja dan produktivitas kerja rendah. Dalam pendekatan yang lebih positif, gaya kepemimpinan dapat diterapkan dengan cara demokratis. Seperti pendapat yang dikemukakan oleh Sudarman Danim "salah satu gaya kepemimpinan yang digunakan dalam dunia pendidikan adalah gaya kepemimpinan demokratis. Gaya ini dianggap sebagai gaya yang ideal dan paling baik terutama untuk kepentingan pendidikan. ${ }^{5}$

Sedangkan Daryanto mengemukakan bahwa kepemimpinan demokratis menempatkan manusia sebagai faktor utama serta yang paling penting dalam sebuah organisasi. Perwujudan dari gaya

2 H. M. Daryanto, Administrasi Pendidikan, Jakarta:Rineka Cipta,2010), h.80

${ }^{3}$ E. Mulyasa, Manajemen $\mathcal{E}$ Kepemimpinan Kepala Sekolah, (Jakarta: Bumi Aksara, 2013, h.17

${ }^{4}$ E. Mulyasa, h. 20

5 Sudarwan Danim, Motivasi Kepemimpinan dan Efektivitas Kelompok, (Jakarta: Rineka Cipta,2004), h. 75 
kepemimpinan ini didominasi perilaku sebagai pelindung, penyelamat, serta perilaku yang cenderung memajukan dan mengembangkan organisasi. Selain itu diwujudkan juga melalui perilaku kepemimpinan sebagai pelaksana. Dengan didominasi oleh ketiga perilaku ke- pemimpinan tersebut, maka dalam gaya ini diwarnai dengan upaya mewujudkan dan mengembangkan hubungan manusiawi yang efektif, berdasarkan prinsip saling menghormati dan menghargai antara yang satu dengan yang lain. ${ }^{6}$

Adanya keterikatan yang kuat antara gaya kepemimpinan yang dipakai oleh kepala sekolah dengan keefektifan secara keseluruhan dari proses pendidikan di sekolah. Artinya, sumber daya manusia yang handal tidak lepas dari pengaruh pola ataupun gaya kepemimpinan yang diterapkan oleh pimpinan, hal ini tercermin dalam pelaksanaan organisasi. Gaya kepemimpinan yang tepat terlihat pada jalannya roda organisasi dengan tertib, nyaman, kondusif dan sesuai dengan tujuan yang hendak dicapai. ${ }^{7}$

Kepemimpinan kepala sekolah di MTsN 6 Kediri selama beberapa periode berjalan dengan baik. Hal ini dibuktikan dari berhasilnya kepala sekolah melaksanakan tugas dan fungsinya. Hingga kini MTsN 6 Kediri merupakan sekolah unggulan yang menjadi pilihan

6 Daryanto, Kepala Sekolah Sebagai Pemimpin Pembelajaran. (Yogyakarta:Gava Media,2011), h. 3

${ }^{7}$ Glatthorn Allan, The Principal as Curriculum Leader: Shaping What Is Taught $\mathcal{E}$ Tested. $2^{\text {nd }} e d$. Thousand Oaks, (Calif:Corwin Press, 2000), h. 12 utama para lulusan tingkat SD/MI untuk melanjutkan ke jenjang SMP di wilayah kecamatan Puncu dan sekitarnya. Di balik suksesnya MTs ini tentunya ada seorang pemimpin sekolah atau kepala sekolah yang berprestasi pula untuk mengatur segala kegiatan yang berkaitan dengan proses belajar mengajar di sekolah maupun di luar sekolah. Ada sosok kepala sekolah yang berprestasi di balik sekolah yang berprestasi, karena keberhasilan sekolah ada di tangan kepala sekolah untuk mengatur rumah tangga sekolah. Keadaan inilah yang memberikan rasa nyaman di MTsN 6 Kediri.

Berdasarkan paparan di atas, menarik sekali untuk melakukan kajian penelitian berkaitan dengan kepemimpinan yang tepat diterapkan di suatu madrasah, untuk itu penulis mengangkat judul "Analisis Kecenderungan Gaya Kepemimpinan Kepala Madrasah Tsanawiyah Negeri $(\mathrm{MTsN}) 6$ Kediri."

\section{Metode}

Penelitian ini merupakan penelitian kualitaif yaitu lebih menekankan realitas sosial sebagai sesuatu yang utuh, kelompok, dinamis, dan bersifat interaktif, untuk meneliti kondisi obyektif yang alamiah. Data yang diperoleh dapat berbentuk kata, gambar, kalimat, skema atau gambar. ${ }^{8}$

8 Sugiyono, Metode Penelitian Pendidikan Pendekatan Kualitatif, Kuantitatif, RED, (Bandung: Alfabeta,2008) , h. 399 
Oleh karena itu penggunaan pendekatan kualitatif dalam penelitian ini adalah dengan mencocokkan antara realita empirik dengan teori yang berlaku dengan menggunakkan metode diskriptif. Pendekatan yang dilakukan dalam penelitian ini adalah pendekatan fenomenologis. Pendekatan fenomenologis secara konseptual adalah sebuah studi penampakan dalam obyek, peristiwa, atau kondisi dalam persepsi individu. ${ }^{9}$ Teori ini digunakan untuk penelitian gaya kepemimpinan yang diterapkan kelapa sekolah MTsN 6 Kediri.

Lokasi yang menjaadi obyek penelitian adalah MTsN 6 Kediri yang merupakan lembaga pendidikan yang terletak di Desa Sidomulyo Kecamatan Puncu Kabupaten Kediri, sebagai lembaga pendidikan yang menjadi kepercayaan masyarakat setempat dan masyarakat sekitar untuk menitipkan putra putri mereka dalam menimba ilmu pengetahuan.

Untuk menentukan data yang akan dipergunakan, maka dibutuhkan teknik pengumpulan data agar bukti-bukti dan fakta-fakta yang diperoleh berfungsi sebagai data objektif. Adapaun metode pengumpulan data yang digunakan dalam penelitian ini ada tiga yakni: observasi, wawancara dan dokumentasi

9 Turnomo Raharjo, Menghargai Perbedaan Kultur, (Yogyakarta: Pustaka Pelajar, 2005). h.2 10 Yukl, G. (2010), Leadership in Organizations, Upper Saddle River, NJ: Pearson, h. 4

11 Hemphill, J. K., and Coons, A. E. , Development of the Leader Behavior Description Questionnaire, Bureau of Business Research, Ohio (State University, Ohio,1957), . 7

\section{Hasil Penelitian dan Pembahasan \\ Konsep Kepemimpinan}

Seiring dengan banyaknya kajian dan penelitian tentang fenomena kepemimpinan, maka konsep tentang kepemimpinan juga terjadi banyak fenomenanya. Tentang konsep kepemimpinan ini Yukl, menuliskan: ${ }^{10}$

a. Kepemimpinan adalah "perilaku individu yang mengarahkan aktivitas kelompok untuk mencapai sasaran bersama" 11

b. Kepemimpinan adalah "pengaruh tambahan yang melebihi dan berada di atas kebutuhan mekanis dalam mengarahkan organisasi secara rutin" 12

Kepemimpinan dilaksanakan ketika seseorang memobilisasi sumber daya institusional, politis, psikologis, dan sumber-sumber lainya untuk membangkitkan, melibatkan dan memenuhi motivasi pengikutnya. ${ }^{13}$

Kepemimpinan adalah proses memberikan tujuan (arahan yang berarti) ke usaha kolektif, yang menyebabkan adanya usaha yang dikeluarkan untuk mencapai tujuan"14

c. Kepemimpinan adalah "kemampuan untuk bertindak diluar budaya...untuk memulai proses

12 Katz, D., \& Kahn, R. L., The social psychology of organizations, (Amerika Serikat:Wiley, 1978), h. 528

13 Burns, J. M. (1978). Leadership, Harper and Row, h. 18

14 Jacobs, T. O., \& Jaques, E. , Military executive leadership, Leadership Library of America (U.S, 1990), h. 281 
perubahan evolusi agar menjadi lebih adaptif" 15

d. "Kepemimpinan adalah proses untuk membuat orang memahami manfaat bekerjasama bersama orang lain, sehingga mereka paham dan mau melakukanya" 16

Sementara itu Yukl (2010) memiliki pendapat sendiri bahwa: Kepemimpinan adalah proses untuk mempengaruhi orang lain untuk memahami dan setuju dengan apa yang perlu dilakukan dan bagaimana tugas itu dilakukan secara efektif, serta proses untuk memfasilitasi upaya individu dan kolektif untuk mencapai tujuan bersama.

Dalam pendapat lain Lussier, Robert N. and Achua Christopher F, menjelaskan bahwa: Leadership is the influencing process of leaders and followers to achieve organizational objective through change. Maksudnya kurang lebih: Kepemimpinan adalah proses mempengaruhi para pemimpin dan pengikut untuk mencapai tujuan organisasi melalui perubahan. Kemudian Fred F. Fielder dalam Rosmiati Tati, dkk. mengemukakan bahwa kepemimpinan adalah individu di dalam kelompok yang memberikan tugas pengarahan dan pengorganisasian yang relevan dengan kegiatan-kegiatan kelompok ${ }^{17}$. Sedangkan Ralp. M Stoqdill, dalam Rosmiati

15 Schein, E. H., Organizational culture and leadership (2nd ed), Jossey-Bass, 1992), h. 2

16 Drath, W. and Palus, C., Making Common Sense: Leadership as meaning-making in a community of practice Greensboro, (U.N_:Center for Creative Leadership, 1994)., h. 4

17 Rosmiati Tati dkk.,, Manajemen Pendidikan, (Bandung: Alfabeta,2009), h. 125

18 Rosmiati Tati dkk, 127
Tati, dkk. memberikan definisi bahwa kepemimpinan adalah proses mempengaruhi kegiatan-kegiatan kelompok yang diorganisir menuju kepada penentuan dan pencapaian tujuan ${ }^{18}$.

Sementara itu George R, Terry dalam Kartono Kartini, berpendapat bahwa: kepemimpinan adalah kegiatan mempengaruhi orang-orang agar mereka suka berusaha mencapai tujuan-tujuan kelompok ${ }^{19}$.

Suhendra, K. mendefinisikan bahwa kepemimpinan adalah kemampuan untuk mempengaruhi perilaku orang lain agar melakukan kegiatan yang diarahkan oleh seorang pemimpin ${ }^{20}$.

Di sisi lain Rosmiati Tati, dkk, memberikan argumentasi bahwa kepemimpinan berarti kemampuan dan kesiapan yang dimiliki oleh seseorang untuk dapat mempengaruhi, mendorong, mengajak, menuntun, menggerakan, dan kalau perlu memaksa orang atau kelompok agar menerima pengaruh tersebut dan selanjutnya berbuat sesuatu yang dapat membantu tercapainya suatu tujuan tertentu yang telah ditetapkan. ${ }^{21}$

Miftah Thoha merumuskan empat sifat umum yang mempengaruhi terhadap keberhasilan kepemimpinan organisasi, yaitu: ${ }^{22}$

1) Kecerdasan,

19 Kartini Kartono, Pemimpin dan Kepemimpinan, Apakah Kepemimpinan Abnormal itu? (Jakarta:, Rajawali Pers, 2010), h57

20 Suhendra K, Manajemen dan Organisasi Dalam Realita Kehidupan, (Bandung:CV. Mandar Maju,2008), h. 65

21 Rosmiati Tati dkk., Manajemen Pendidikan, Jakarta: Pustaka Pelajar, 2009) h. 125

22 Rosmiati Tati dkk.., h. 33 
Hasil penelitian pada umumnya membuktikan bahwa pemimpin mempunyai tingkat kecerdasan yang lebih tinggi dibandingkan dengan yang dipimpin. Namun demikian, yang sangat menarik dari penelitian tersebut ialah pemimpin tidak bisa melampaui terlalu banyak dari kecerdasan pengikutnya.

2) Kedewasaan dan keluasan hubungan sosial.

Pemimpin cenderung menjadi matang dan mempunyai emosi yang stabil, serta mempunyai perhatian yang luas terhadap akitivitas-aktivitas sosial. Dia mempunyai keinginan menghargai dan dihargai.

3) Motivasi diri dan dorongan berprestasi.

Para pemimpin seara realatif mempunyai dorongan motivasi yang kuat untuk berprestasi. Mereka bekerja berusaha mendapatkan penghargaan yang intrinsik dibandingkan dari yang ekstrinsik.

Miftah Thoha, menjelaskan bahwa Path-Goal Theory, teori ini sebenarnya dimulai oleh Georgepoulos dan kawankawan, kemudianya dalam pengembanganya yang modern diungkapkan oleh Martins Evans dan Robert House. ${ }^{23}$ Path-Goal Theory, versi House dalam Miftah Thoha, memasukan empat tipe,

1. Kepemimpinan Direktif.

Tipe ini sama dengan model kepemimpinan yang otokratis dari Lippitt dan White. Bawahan tahu dengan pasti apa yang diharapkan darinya dan

${ }^{23}$ Rosmiati Tati dkk.., h. 44

${ }^{24}$ Rosmiati Tati dkk.., h. 42 yang dapat dijelaskan sebagai berikut ${ }^{24}$ :

pengarahan yang khusus diberikan oleh pemimpin. Dalam model ini tidak ada partisipasi dari bawahan.

2. Supportive leadership

Kepemimpinan model ini mempunyai kesediaan untuk menjalankan sendiri, bersahabat, mudah didekati, dan mempunyai perhatian kemanusiaan yang murni terhadap para bawahanya.

Kepemimpinan Partisipatif. Pada gaya kepemimpinan ini pemimpin berusaha meminta dan menggunakan saran-saran dari para bawahannya. Namun pengambilan keputusan masih tetap berada padanya.

Kepemimpinan yang berorientasi pada prestasi. Gaya kepemimpinan ini menetapkan serangkaian tujuan yang menantang para bawahannya untuk berpartisipasi. Pemimpin juga memberikan keyakinan kepada mereka bahwa mereka mampu melaksanakan tugas pekerjaan mencapai tujuan secara baik.

Kepemimpinan dalam Islam dikenal dengan istilah ulil amri. yang berarti pemerintah, ulama, cendikiawan atau tokoh-tokoh masyarakat yang menjadi tumpuan ummat, menerima kepercayaan atau amanat dari masyarakat. ${ }^{25}$ Sebagaimana dalam firman Allah SWT dalam surat An-Nisa' ayat 59

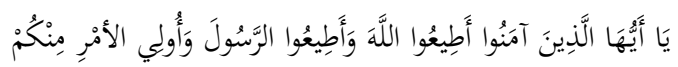

Artinya: "Hai orang-orang yang beriman, taatilah Allah dan taatilah Rasul
25 Imam Modjiono (2002), Kepemimpinan Dan Keorganisasian, (Yogyakarta: UII Press), h. 10 
(Nya), dan ulil amri di antara kamu." 26

Kepemimpinan adalah terjemahan dari kata leadership yang berasal dari kata leader. Pemimpin (leader) adalah orang yang memimpin, sedangkan pemimpin merupakan jabatannya. Dalam pengertian lain, secara etimologi istilah kepemimpinan berasal dari kata dasar pimpin, yang artinya membimbing atau tuntun dari kata dasar pimpin lahirlah kata kerja memimpin yang artinya membimbing dan menuntun. ${ }^{27}$

\section{Prinsip Kepemipinan Kepala Sekolah}

Profesionalisme kepala sekolah dapat tercapai apabila seorang kepala sekolah memiliki dan memahami prinsipprinsip sebagai pemimpin pendidikan. Berdasarkan Peraturan Menteri Pendidikan Nasional (permendiknas) No. 13 Tahun 2007. “Kepala sekolah adalah seorang guru yang memiliki tugas tambahan untuk membina dan memimpin anggotanya untuk mencapai tujuan".28

Agar kepala sekolah dalam melaksanakan kepemimpinannya dapat berjalan dengan harmonis sesuai dengan yang diinginkan, kepala sekolah harus memiliki prinsip-prinsip yang dapat ditetapkan, yaitu :

1. Prinsip pelayanan, bahwa kepemimpinan sekolah harus menerapkan unsur-unsur pelayanan

26 Departemen Agama RI, Al Qur'an Dan Terjemahnya..., (Jakarta:Depag RI).h. 128

27 Ara Hidayat \& Imam Machali (2012), Pengelolaan Pendidikan, Konsep, Prinsip, Dan ㄱ Aplikasi Dalam Mengelola Sekolah Dan Madrasah, フ (Yogyakarta: Penerbit Kaukaba,2012), h. 75 dalam kegiatan

operasional sekolahnya.

2. Prinsip persuasi, pemimpin dalam menjalankan tugasnya harus memperhatikan situasi dan kondisi setempat demi keberhasilan keberhasilan kepemimpinannya yang sedang dan yang akan dilaksanakan.

3. Prinsip bimbingan, pemimpin pendidikan hendaknya membimbing peserta didik kearah tujuan yang ingin dicapai sesuai dengan perkembangan peserta didik yang ada dilembaganya.

4. Prinsip efisiensi, mengarah pada cara hidup yang ekonomis dengan pengeluaran sedikit untuk memperoleh keuntungan yang sebesar-besarnya.

5. Prinsip berkesinambungan, agar pemimpin pendidikan ini diterapkan tidak hanya pada satu waktu saja, tetapi perlu secara terus menerus. ${ }^{29}$

Sementara itu, daryanto menyatakan ada tiga syarat yang harus dipenuhi untuk menjadi kepala sekolah, yaitu;

1) Aspek Akseptabilitas

Akseptabilitas adalah aspek mengandalkan dukungan riil dari komunitas yang dipimpinnya. Seorang kepala sekolah harus mendapat dukungan dari guru-guru dan karyawan dalam lembaga yang bersangkutan sebagai komunitas formal yang

28 Peraturan Menteri Pendidikan Nasional, 2007. Tentang Standar Kepala Sekolah/Madrasah Nomor 13 Tanggal Tahun 2007

29 Yatik dalam http://yatikkepemimpinandalampendidikan.blogspot.co.id/. Diakses pada selasa 29/8/2019 pukul 20.00 WIB 
dipimpinnya. Dukungan ini juga secara nonformal harus didapati dari masyarakat termasuk komite sekolah sebagai wadah organisasi orang tua atau wali peserta didik. Aspek akseptabilitas ini dalam teori organisasi disebut legitimasi atau pengakuan, yaitu kelayakan seorang pemimpin untuk diakui dan diterima keberadaanya oleh mereka yang dipimpin. Dan untuk mendapatkan legitimasi tersebut sebaiknya kepala sekolah dipilih langsung oleh guru-guru. Kepala sekolah yang dipilih melalui proses pemilihan seperti ini biasanya mendapat dukungan yang nyata. Tentunya melalui tahapan seleksi yang ketat atau tidak asal memilih kepemimpinan seperti ini akan memiliki pengakuan yang sangat kuat jika melalui proses pemilihan langsung yang dilaksanakan secara adil, jujur, dan transparan.

2) Aspek Kapabilitas

Aspek Kapabilitas menyangkut kompetensi atau kemampuan untuk menjalankan kepemimpinan. Untuk menjadi kepala sekolah tidak hanya cukup mendapat pengakuan dari guruguru sebagai pendukungnya, tetapi juga harus memiliki kemampuan memimpin. Selain itu juga perlu memiliki kemampuan dalam mengelola sumer daya yang ada dari orang-orang yan dipimpinnya agar tidak menimbulkan konflik. Kapabilitas ini berupa pengalaman yang

30 Daryanto, Kepala Sekolah Sebagai Pemimpin Pembelajaran, (Bandung:Gava Media, 2011), h. 2425

31 Wahyudi, Kepemimpinan Kepala Sekolah dalam Organisasi Pembelajar (Learning Jurnal Intelektual: Jurnal Pendidikan dan Studi Keislaman Volume 9, Nomor 2, Agustus 2019 cukup memadai serta pengetahuan mengenai manajemensekolah dan kompetensi pendukung lainnya yang sangat diperlukan oleh seorang kepala sekolah. 3) Aspek Integritas

Secara sederhana, integritas artinya komitmen moral dan berpegang teguh terhadap aturan main yang telah disepakati sesuia dengan peraturan dan norma yang semestinya berlaku. Faktor ini akan menentukan wibawa dan tidaknya seorang kepala sekolah. Aspek integritas akan menjadi sebuah persyaratan sempurna jika aspek akseptabilitas dan kapabilitas terpenuhi. Jadi, integritas adalah menyangkut konsistensi dalam memegang teguh aturan main atau norma-norma yang berlaku didunia pendidikan. ${ }^{30}$

\section{Gaya Kepemimpinan dalam Pendidikan}

“Gaya kepemimpinan adalah cara pemimpin berperilaku secara konsisten terhadap bawahan sebagai anggota kelompoknya." 31

Berbeda dengan penjelasan di atas bahwa gaya kepemimpinan adalah tindakan menyeluruh dari seorang pemimpin baik secara langsung maupun tidak langsung agar tercapainya tujuan. Sejumlah ahli teori kepemimpinan menekankan style dari pemimpin yang efektif, yaitu berkisar pada kepemimpinan gaya partisipatif, nonpartisipatif, otokratik, demokratik, atau laissezfaire. ${ }^{32}$

Organization), (Bandung:CV. Alfabeta, 2009), h. 123

32 Syaiful Sagala, Administrasi, h. 150 
Berdasarkan pengertian kepemimpinan yang dikemukakan para ahli di atas, menurut penulis gaya kepemimpinan kepala sekolah adalah sebuah cara seorang pemimpin (kepala sekolah) dalam melakukan fungsi dan tugasnya agar tercapainya suatu tujuan. Sejalan dengan pendapat tersebut, menurut Bill Woods. ${ }^{33}$ ada tiga gaya kepemimpinan yakni:

\section{Otokratis}

Menurut Syaiful kepemimpinan otokratis adalah pemimpin yang membuat keputusannya sendiri. Pemimpin memikul tanggung jawab dan wewenang penuh. ${ }^{34}$

Kepemimpinan otokratis merupakan gaya kepemimpinan yang semua kendali dipegang oleh pemimpinnya. Pemimpin yang menggunakan gaya ini cenderung bersikap sewenang-wenang terhadap bawahannya. Ciri-ciri pemimpin yang otokrasi. ${ }^{35}$

a. Menganggap organisasi yang dipimpinnya sebagai milik pribadi.

b. Menganggap bawahan sebagai alat semata.

c. Tidak mau menerima pendapat, saran, dan kritik.

d. Cara menggerakkan bawahan dengan pendekatan paksaan dan bersifat mencari kesalahan/menghukum.

\section{Demokratis}

Menurut Ngalim kepemimpinan demokratis atau partisipatif adalah pemimpin melakukan konsultasi dengan kelompok mengenai masalah yang menarik perhatian mereka dimana mereka dapat menyumbangkan sesuatu. Menurut penulis gaya kepemipinan demokratis adalah pemimpin yang lebih mementingan kepentingan bawahan, bawahan atau anggota kelompok diberikan keleluasaan untuk berpendapat.

3. Laissez-faire (Kendali Bebas)

Menurut Syaiful kepemimpinan ini adalah pemimpin memberi kekuasaan pada bawahan, kelompok dapat mengembangkan sasarannya sendiri dan memecahkan masalahnya sendiri, tidak ada pengarahan dari pemimpin. Gaya ini biasanya tidak berguna, tetapi dapat menjadi efektif dalam kelompok profesional yang termotivasi tinggi. ${ }^{36}$

\section{Temuan Penelitian dan Pembahasan}

\section{Pengambilan Keputusan Kepala}

\section{Madrasah}

Mekanisme pengambilan keputusan kepala MTs Negeri 6 Kediri mengedepankan pada musyawarah dewan guru. Maka untuk mengkaji setiap keputusan yang sudah disepakati, dilakukanlah sebuah pertemuan khusus dewan guru untuk mengambil alternatif solusi setiap pemecahan masalah.

Sesekali dalam situasi tertentu, juga diterapkan sistem bottom-up atau memberi tugas kepada semua pihak termasuk guru karyawan untuk

35 Ngalim Purwanto (1995), Administrasi dan Supervisi Pendidikan, (Bandung: PT. Remaja Rosda Karya,1995) h. 50-52

36 Syaiful Sagala, Administrasi, h. 151 
membuat program-program yang nantinya akan dibahas dalam rapat. Tapi semuanya juga melihat topik pembahasannya apa, agar sesuai dengan petunjuk teknis yang telah ditetapkannya. Karena jika tidak sesuai dengan topik pembahasan bukan tidak mungkin rapat itu gagal dilaksanakan. Kewenangan dalam melakukan pengambilan keputusan secara mutlak memang menjadi kewenangan seorang kepala madrasah. Namun kadangkala juga kewenangan ada pada wakil kepala madrasah tapi itu sifatnya koordinatif, tetap semua ada pada kendali kepala madrasah sebagai ujung tombak serta penanggung jawab utama jalannya lembaga pendidikan.

Hasil penelitian membuktikan bahwa mekanisme pengambilan keputusan yang dilakukan oleh kepala madrasah di MTs Negeri 6 Kediri melalui kegiatan identifikasi awal terhadap unit permasalahan, merumuskan tujuan penyelesaian masalah, identifikasi berbagai alternatif solusi, menentukan kriteria pemilihan alternatif solusi, dan menentukan pilihan alternatif solusi sehingga menjadi kumpulan keputusan atau kebijakan.

\section{Pola Komunikasi Kepala Madrasah}

Peranan kepala madrasah adalah perihal penting dalam manajemen madrasah. Di MTs Negeri 6 Kediri kepala madrasah mempunyai kedudukan yang paling tinggi. Selain tugasnya sebagai pengatur madrasah, dia juga merupakan pucuk pimpinan madrasah. Oleh karena itu, peranannya harus menunjukkan kepandaiannya dalam mengurus madrasah. Sedangkan guru merupakan pasukan pendidik yang kepemimpinannya di bawah komando kepala madrasah. Di samping tugasnya mengajar dia juga harus turut serta berperan memajukan dan mengembangkan madrasah tersebut. Maka dengan demikian, partisipasi guru sangatlah dibutuhkan untuk bekerja sama dengan seluruh pihak madrasah termasuk kepala madrasah sendiri untuk memajukan dan mengembangkan madrasahnya.

Berdasarkan hasil pengamatan penulis, kepala MTs Negeri 6 Kediri memiliki karakter yang baik dalam mengelola komunikasi/hubungannya dengan para gurunya. Sedikitnya berikut ini adalah hal-hal yang biasa dilakukan oleh kepala madrasah guna menjaga hubungan komunikasi dengan para guru, yaitu:

1. Kepala madrasah selalu memberikan ruang aspirasi kepada guru-guru.

2. Kepala madrasah memberikan kebebasan kepada guru untuk menunjukkan kemampuannya mendidik peserta didik dengan berbagai kreatifitas seorang guru.

3. Di luar jam kerja, kepala madrasah sering berkumpul santai dengan para guru untuk menjaga hubungan kekeluargaan. Artinya, secara personal keduanya selalu menjaga hubungan kekeluargaan dengan baik.

4. Kepala madrasah berusaha untuk selalu transparan dalam mengelola sekolah, dan juga dalam hal urusan informasi dan kesempatan bagi guru. 
5. Kepala madrasah selalu mengajak berdialog dan musyawarah jika mendapatkan permasalahan yang melibatkan warga madrasah dan guru.

Dari beberapa uraian di atas tadi, dapat disimpulkan bahwa kepala MTs Negeri 6 Kediri memang tidak membatasi diri dalam hal waktu dan tempat untuk saling berinteraksi dengan para guru di MTs Negeri 6 Kediri tersebut.

\section{Motivasi Kepala Madrasah}

Diantara tugas kepala madrasah adalah sebagai motivator kepada para guru, staf, dan siswa. Upaya yang saya lakukan untuk memtivasi para guru dan staf diantaranya:

1. Menciptakan kebersamaan di antara guru dan staf

2. Menciptakan rasa aman di dalam lingkungan madrasah

3. Memberikan saran dan anjuran untuk memelihara serta meningkatkan semangat para guru, staf dan siswa

4. Bertanggung jawab memenuhi dan menyediakan dukungan yang diperlukan oleh para guru

5. Selalu dapat memperhatikan, menghargai apapun yang dihasilkan oleh para guru, staf dan siswa

Dari penjelasan itu sangat jelas terlihat bahwa kepala MTs Negeri 6 Kediri melakukan upaya keras agar para guru, staf bisa termotivasi dalam bekerja. Tidak hanya menuntut untuk bekerja maksimal semata.

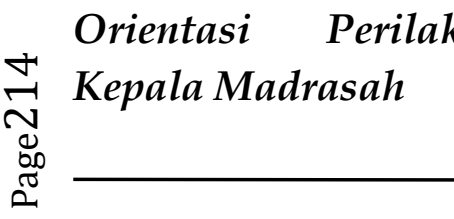

kepemimpinan
Berikut ini adalah hasil penelitian tentang perilaku kepala madrasah MTs Negeri 6 Kediri.

1. Memberikan keteladanan dalam kedisiplinan.

2. Perilaku kepemimpinan yang tegas.

3. Perilaku kepemimpinan yang optimis dan semangat.

4. Perilaku kepemimpinan yang bijaksana.

5. Perilaku kepemimpinan yang rendah hati.

\section{Prestasi MTs Negeri 6 Kediri}

Berikut sederet prestasi yang diukir madrasah ini selama beberapantahun. Tahun 2019 yaitu Finalis olimpiade Matematika nasional, Juara kedua lomba hadrah Al-banjari tingkat Jawa Timur, Juara Pramuka se-Jawa Timur. Tahun 2018, Finalis Olimpiade Matematika nasional, Juara ke dua lomba Pramuka nasional Juara pramuka se-Jawa Timur. Tahun 2017, Juara umum olimpiade pelajaran UN tingkat Jawa Timur, Juara pramuka se-Jawa Timur, Finalis Olimpiade Matematika nasional. Tahun 2016, Peringkat kedua UN Kab. Kediri, Juara pramuka se-Jawa Timur, Finalis olimpiade Matematika nasional.

\section{Kesimpulan}

Berdasarkan hasil penelitian di atas dapat disimpulkan:

1. Gaya kepemimpinan Kepala Madrasah menggunakan Tsanawiyah Negeri (MTsN) 6 Kediri teori kepemimpinan situasional atau acak sesuai dengan kebutuhan masalah yang dihadapi. Pendekatan yang 
dilakuka adalah pendekatan

penyelesaian masalah (problem

solving).

2. Kepala Madrasah Tsanawiyah Negeri (MTsN) 6 Kediri mampu membawa peserta didiknya berprestasi dengan berbagai program unggulan. Prestasi ini terlihat semakin baik dari tahun ke tahun. 


\section{Daftar Pustaka}

Danim, Sudarwan (2004), Motivasi Kepemimpinan dan Efektivitas Kelompok, Rineka Cipta, Jakarta.

Daryanto, H. M. (2010), Administrasi Pendidikan, Rineka Cipta, Jakarta

Daryanto (2011), Kepala Sekolah Sebagai Pemimpin Pembelajaran. Gava Media, Yogyakarta.

Hidayat, Ara \& Imam Machali (2012), Pengelolaan Pendidikan, Konsep, Prinsip, Dan Aplikasi Dalam Mengelola Sekolah Dan Madrasah, Penerbit Kaukaba, Yogyakarta.

Glatthorn Allan (2000), The Principal as Curriculum Leader: Shaping What Is Taught \& Tested. 2nded. Thousand Oaks, Corwin Press, Calif.

Kontjaraningrat (1991), Metode-metode Penelitian Masyarakat, Gramedia, Jakarta.

Marno dan Triyo Supriyatno (2008), Manajemen dan Kepemimpinan Pendidikan Islam, Refika Aditama, Bandung.

Moleong, Lexy J. (2000), Metodologi Penelitian Kualitatif, Remaja Rosda karya, Bandung.

Mulyasa, E. (2013), Manajemen $\mathcal{E}$ Kepemimpinan Kepala Sekolah, Bumi Aksara, Jakarta.

Nasution (2003), Metode Penelitian Naturalistik Kualitatif, Thersito, Bandung.

Purwanto, Ngalim (1995), Administrasi dan Supervisi Pendidikan, PT. Remaja Rosda Karya, Bandung,
Raharjo, Turnomo (2005), Menghargai Perbedaan Kultur, Pustaka Pelajar, Yogyakarta.

Rukmana, Ade. Asep Suryana (2006), Pengelolaan Kelas, UPI PRESS, Bandung.

Sagala, Syaiful (2008), Administrasi Pendidikan Kontemporer, CV. Alfabeta, Bandung.

Sudjana, Nana \& Awal Kusumah (2000), Proposal Penelitian di Perguruan Tinggi, PT. Sinar Baru Algensindo, Bandung.

Sugiyono (2008), Metode Penelitian Pendidikan Pendekatan Kualitatif, Kuantitatif, RED, Alfabeta, Bandung.

Suryabrata, Sumadi (1998), Metodologi Penelitian,Raja Grafindo Persada, Jakarta.

Usman, Husaini (1996), Metodelogi Penelitian Sosial, Bumi Aksara, Jakarta.

Wahyudi (2009), Kepemimpinan Kepala Sekolah dalam Organisasi Pembelajar (Learning Organization), CV. Alfabeta, Bandung.

Yuniar, Tanti, Sip. (TT), Kamus Lengkap Bahasa Indonesia, Agung Media Mulia, Surabaya. 